\title{
Hydroxyapatite (HAp) From Tenggiri Fish Bones As Abrasive Material In Toothpaste Formula
}

\author{
Lia Anggresani ${ }^{1}$, Yoli Nopita Sari ${ }^{1}$, Rahmadevi $^{2} *$ \\ ${ }^{1}$ Pharmacy Department, Harapan Ibu Jambi College of Health Sciences \\ J1. Tarmizi Kadir No. 71 Pakuan Baru Jambi, Jambi, 36132, Indonesia \\ ${ }^{2}$ Pharmacy Department, Adiwangsa University \\ Jl. Sersan Muslim No. 24, The Hok, North Jambi, Jambi, 36131, Indonesia \\ *Corresponding author : zuldev1807@gmail.com
}

Received: January 2021; Revision: February 2021; Accepted: May 2021; Available online: June 2021

\begin{abstract}
Cavities are one of the factors of dental and oral health problems that can be prevented by brushing teeth using toothpaste. Toothpaste can be made from a variety of chemicals, one of which is hydroxyapatite (HAp) which has good biocompatible properties. Hydroxyapatite can be obtained by utilizing tenggiri fish bone waste which has the main element of calcium. Fish bones soaked with $\mathrm{NaOH}$ and acetone are then calcined at $800{ }^{\circ} \mathrm{C}$ for 3 hours to obtain $\mathrm{CaO}$ powder and characterized its elemental content using X-Ray Fluorescence (XRF). $\mathrm{CaO}$ obtained was then reacted with $\left(\mathrm{NH}_{4}\right)_{2} \mathrm{HPO}_{4}$ with a mole ratio of $\mathrm{Ca} / \mathrm{P} 1.67$ then heated at $90{ }^{\circ} \mathrm{C}$, added $\mathrm{NaOH}$ up to $\mathrm{pH} 12$, then the obtained deposits are filtered and calcined at $900{ }^{\circ} \mathrm{C}$. The solids obtained from the calcination are then characterized using X-Ray Diffraction (XRD) and Scanning Electron Microscope (SEM). Hydroxyapatite (HAp) was formulated into toothpaste with the concentrations of $0 \%(\mathrm{~F} 0), 45 \%(\mathrm{~F} 1), 50 \%(\mathrm{~F} 2)$, and $55 \%(\mathrm{~F} 3)$. Toothpaste was evaluated using organoleptic tests, homogeneity tests, foam height tests, spreadability tests, $\mathrm{pH}$ and hedonic tests. XRD analysis shows that the resulting hydroxyapatite (HAp) has a crystal structure in accordance with ICSD standard No. 96-900-3549. SEM analysis showed that granular particles measuring $0.1 \mu \mathrm{m}-0.3 \mu \mathrm{m}$ in size. All formulated toothpastes (F0, F1, F2, and F3) meet the requirements of a good toothpaste. Hydroxyapatite (HAp) can be formulated into a good toothpaste with a concentration of $45 \%$.
\end{abstract}

Keywords: Tenggiri fish bones, Hydroxyapatite (HAp), toothpaste

DOI: $10.15408 / j k v \cdot v 7 i 1.19165$

\section{INTRODUCTION}

Dental and oral health is part of the overall health of the body and is inseparable from the health of the body in general. Teeth and mouth problems can affect the quality of life, including speech function, pain reduced confidence, and interfere with daily activities (Ahmad, 2017). Cavities are one of the factors that become dental and oral health problems. Cavities are caused by the erosion of dental emails, which can occurred due to many things, such as consuming sweet foods, microbial activity in the mouth, and also saliva activity (Wadu et al., 2015). To prevent dental and oral health problems, brushing the teeth is one of the solution. Teeth brushing using toothpaste is recommended twice a day, i.e. after meals and before going to bed. The use of toothpaste is chosen because it is more practical and can cover micro-sized holes in the teeth as well as reduce the potential for other holes to form (Wadu et al., 2015).

Toothpaste contains a wide range of chemical compounds, one of which contains hydroxyapatite (HAp) which is effective for closing holes in the teeth (Wadu et al., 2015). Hydroxyapatite (HAp) with the chemical formula $\mathrm{Ca}_{10}\left(\mathrm{PO}_{4}\right)_{6}(\mathrm{OH})_{2}$ is often applied to the field of bones and teeth because it has good biocompatible properties in human tissues and its composition is almost the same as bone (Riyanto \& Maddu, 2014).

One of the efforts to synthesis hydroxyapatite (HAp) is to utilize the waste of 
tenggiri fish bone because many household industries in Jambi produce pempek, tekwan, and crackers that only use the meat of tenggiri. Fish bones have a high calcium $(5.63 \mathrm{~g} / \mathrm{kg})$ and phosphorus content $(2.38 \mathrm{~g} / \mathrm{kg}$ ) (Stanek et al., 2013). Where calcium and phosphorus are the main elements of hydroxyapatite formation (HAp) (Susanti et al., 2011). Hydroxyapatite can be synthesized from chemicals and natural materials such as from mollusk shell (Wattanutchariya \& Changkowchai, 2014), mackerel bones (Anggresani et al., 2018), chicken bones (Rajesh et al., 2012), limestone of Bukit Tui in Padangpanjang (Anggresani, 2016), cockle shells (Azis et al., 2015), tuna bones (Hanura et al., 2017), and cow bones (Haris et al., 2016).

The hydroxyapatite has been used in the pharmacy fields such as tablet making (Mustaqim, 2017), dental implant (Sidiqa et al., 2012), injection manufacture (Budiatin et al., 2016). However, there was not an investigation on making toothpaste from hydroxyapatite tenggiri fish bone, hence this studyis conducted to investigate hydroxyapatite toothpaste that can cover the holes in the teeth.

\section{MATERIALS AND METHODS The formation of Calcium Oxide ( $\mathrm{CaO}$ )}

$8 \mathrm{~kg}$ Tenggiri fish bone waste (Scomberomerus guttatus) was cleaned and boiled for 45 minutes then rinsed. The bones were soaked with $0.1 \% \mathrm{NaOH} 10 \mathrm{~L}$ for 7 hours and $50 \%$ acetone for 8 hours. Then, the bones are drained and dried for 7 days then crushed. The bones were calcined at $800{ }^{\circ} \mathrm{C}$ for 3 hours using a furnace until it formed the powder. The powder was crushed and sieved with mesh 80 . The bones powder of mackerel $(\mathrm{CaO})$ was then analyzed by XRF PAnalytical Epsilon 3.

\section{Hydroxyapatite Synthesis}

337.0328 gram of $\mathrm{CaO}$ powder was diluted with $2 \mathrm{~L}$ aquadest. The solution was stirred for 30 minutes at $300 \mathrm{rpm}$ so that the suspension of $\mathrm{Ca}(\mathrm{OH})_{2}$ was formed. $\left(\mathrm{NH}_{4}\right)_{2} \mathrm{HPO}_{4}$ was used as phosphate precursors. The suspension of $\mathrm{Ca}(\mathrm{OH})_{2}$ mixed with $\left(\mathrm{NH}_{4}\right)_{2} \mathrm{HPO}_{4}$ was generated with a 1.67 mole ratio of $\mathrm{Ca} / \mathrm{P}$ and heated at $90{ }^{\circ} \mathrm{C}$ for 1 hour. $\mathrm{NaOH} 1 \mathrm{M}$ added to contour the $\mathrm{pH}$ until it reaches 12 . Let the mixture stands for 24 hours at room temperature. Then the formed deposit was filtered and dried using oven at $120^{\circ} \mathrm{C}$ for 5 hours. The dry precipitate was calcined at $900{ }^{\circ} \mathrm{C}$ for 5 hours (Haris et al., 2016). Precipitation process is an alkaline acid reaction that produces crystalline solids as well as water. This process requires only cheap raw materials, relatively simple chemical reactions as well as particle size and homogeneity that tends to be quite good (Haris et al., 2016).

\section{Toothpaste Preparation}

The synthesis of hydroxyapatite (HAp) toothpaste from mackerel bone begins with 1 part of Na-CMC expanded with hot aquadest in beaker glass and let remain for 15 minutes continue by stirred firmly. Hydroxyapatite (HAp) was crushed in mortar according to formula ( $\mathrm{F} 0\left(\mathrm{CaCO}_{3} 55\right.$ parts), $\mathrm{F} 1$ (HAp 45 parts), F2 (HAp 50 parts), F3 (HAp 55 parts)), then added 0.1 part of titanium dioxide, 0.1 part of methyl paraben, and 0.2 parts of saccharine. The dispersion of $\mathrm{Na} \mathrm{CMC}$ that has dissolved was crushed vigorously until homogeneous, then added 2 parts of SLS and 30 parts of glycerine. Oleum menthae piperitae dripped into the paste and crushed until homogeneous. After that, the paste preparation was inserted into the tube and evaluated.

Table 1. The formulation of toothpaste

\begin{tabular}{lcccc}
\hline \multirow{2}{*}{ Ingredients } & \multicolumn{4}{c}{ Composition (\%) } \\
\cline { 2 - 5 } & Fo & F1 & F2 & F3 \\
\hline Hydroxyapatite & - & 45 & 50 & 55 \\
Calcium Carbonate & 55 & - & - & - \\
Na-CMC & 1 & 1 & 1 & 1 \\
Glyserin & 30 & 30 & 30 & 30 \\
Methyl Paraben & 0.1 & 0.1 & 0.1 & 0.1 \\
Sakaryn & 0.2 & 0.2 & 0.2 & 0.2 \\
Sodium lauryl sulfat & 2 & 2 & 2 & 2 \\
Titanium dioxide & 0.1 & 0.1 & 0.1 & 0.1 \\
Oleum menthae Piperitae & $\mathrm{qs}$ & $\mathrm{qs}$ & $\mathrm{qs}$ & $\mathrm{qs}$ \\
Aquadest & add 100 & add 100 & add 100 & add 100 \\
\hline
\end{tabular}




\section{Toothpaste Evaluation}

Toothpaste preparations that have been made should be evaluated. Toothpaste evaluations include:

\section{Organoleptic Test}

Organoleptic observations of toothpaste include shape (consistency), color, and aroma that were objectively observed (Syurgana $e t$ al., 2017).

\section{pH Test}

$\mathrm{pH}$ measurement was done using $\mathrm{pH}$ meter, which calibrated by using buffer phosphate solution with $\mathrm{pH} 10$, buffer phosphate $\mathrm{pH} 7.0$ and buffer phosphate $\mathrm{pH} 4.0$ by dipping $\mathrm{pH}$ electrodes and temperature stick into the dapar solution. Once calibrated, the $\mathrm{pH}$ measurement of the aquadest is ready to use.. Weigh 1 gram of hydroxyapatite toothpaste (HAp) from the bones of the mackerel and diluted with $10 \mathrm{ml}$ of aquadest. Dip the $\mathrm{pH}$ electrodes and temperature sticks into the prepared paste that has been diluted until the needle monitor shows a stable number and read the $\mathrm{pH}$ on the monitor (Ali et al., 2015).

\section{Homogeneity Test}

Homogeneity test was done by means of toothpaste to be tested weighed as much as 0.1 grams and then placed between two layers of glass objects to be observed homogeneity. If there are no coarse grains on the glass of the object, then the toothpaste was declared homogeneous, while the presence of coarse grains indicates that the toothpaste was not homogeneous (Syurgana et al., 2017).

\section{Scatter Power Test}

Scatter power test was carried out by placing $a \pm 1$ gram of toothpaste preparation between two transparent plastics and then given a load from the smallest size to the largest size, then measured the size of the spread diameter formed at each load increase ( $2 \mathrm{~g}, 4 \mathrm{~g}$, and $6 \mathrm{~g}$ ) (Ismail et al., 2014).

\section{Foam Formation Test}

Foam formation test was carried out by making a solution of $1 \%$ of the various concentrations of hydroxyapatite (HAp) toothpaste from the bones of mackerel in water. In a measuring glass, the solutions poured and covered with aluminium foil. The foam shaked and the foam height was measured at 0 and 5 minutes (Syurgana et al., 2017).

\section{Stability Test}

Stability test was carried out by storing hydroxyapatite (HAp) toothpaste from mackerel bones at different temperatures at 4 ${ }^{\circ} \mathrm{C}$, room temperature, and $40{ }^{\circ} \mathrm{C}$ for 21 days. Then it keeps observed seen whether organoleptic, $\mathrm{pH}$, homogeneity, scatter power and foam changes formed on the $7^{\text {th }}$ day, $14^{\text {th }}$ day and $21^{\text {st }}$ day (Nagajyothi et al., 2014).

\section{Hedonic Test}

Hedonic test was carried out to determine the respondent's level of preference for hydroxyapatite toothpaste (HAp) preparations from the bones of the mackerel made. Respondents as many as 20 people with the following criteria: male or female sex, age 17-25 years. Aspects assessed include parameters of color, aroma, taste, and texture The product then being assessed by the respondent to observe the response whether the respondents like the product. (Dian et al., 2014).

\section{RESULTS AND DISCUSSION The Formation of Calcium Oxide ( $\mathrm{CaO}$ )}

The formation of mackerel bone powder $(\mathrm{CaO})$ begins with the boiling process for 45 minutes, which will facilitate the cleansing of the bones from the remaining meat that was still attached, after which the fish bones were soaked with $\mathrm{NaOH} 0.1 \%$ for 7 hours then soaked with acetone $50 \%$ for 8 hours to reduce the fat levels contained in the bones of mackerel. The calcination of the sample done by using a furnace with a temperature of 800 ${ }^{\circ} \mathrm{C}$ for 3 hours to remove carbonate that can inhibit crystal formation and eliminate all organic elements contained in the bones of mackerel. (Royani et al., 2016) mentioned the decomposition of $\mathrm{CaCO}_{3}$ into $\mathrm{CaO}$ ideally occurs at a temperature of $800{ }^{\circ} \mathrm{C}$. At this stage, there was a decomposition reaction of calcium carbonate $\left(\mathrm{CaCO}_{3}\right)$ to calcium oxide $(\mathrm{CaO})$ Reactions that occurred according to eq. $1:$

$$
\mathrm{CaCO}_{3} \longrightarrow \mathrm{CaO}+\mathrm{CO}_{2} \quad \text { (equation 1) }
$$

$\mathrm{XRF}$ analysis is conducted to determine the chemical composition in the bones of tenggiri (Manggara, 2018). Table 2 showed 
that calcium oxide contained in the bones of mackerel fish by $49.846 \%$ therefore it can be used as a precursor of calcium in the formation of hydroxyapatite compounds. The minimum condition of calcium concentration as an abrasive in making toothpaste was 35\% (Jadge \& Patil, 2008). (Mutmainnah et al., 2017) investigated $\mathrm{CaO}$ in Tuna Bones which contained $62.31 \% \quad \mathrm{CaO}$ content and (Anggresani et al., 2018) investigated $\mathrm{CaO}$ in Tenggiri Bones which contained 50.814\% $\mathrm{CaO}$ content. The results obtained are smaller compared to previous studies since the sample was still black after calcination which indicated that there was a process of degradation of organic material that occurred (Mutmainnah et al., 2017).

Table 2. XRF analysis result of Tenggiri Bone

\begin{tabular}{cc}
\hline Oxide Compound & Concentration (\%) \\
\hline $\mathrm{CaO}$ & 49.846 \\
$\mathrm{P}_{2} \mathrm{O}_{5}$ & 26.195 \\
$\mathrm{MgO}$ & 2.074 \\
$\mathrm{Al}_{2} \mathrm{O}_{3}$ & 0.712 \\
$\mathrm{SiO}_{2}$ & 0.234 \\
\hline
\end{tabular}

\section{Hydroxyapatite Synthesis (HAp)}

In this study, the hydroxyapatite was made using precipitation methods. $\mathrm{CaO}$ powder which is the source of calcium in the fabrication of hydroxyapatite (HAp) was dissolved with water to get calcium hydroxide $\left(\mathrm{Ca}(\mathrm{OH})_{2}\right)$. Reactions that occurred according to eq. 2 :

$$
\mathrm{CaO}+\mathrm{H}_{2} \mathrm{O} \longrightarrow \mathrm{Ca}(\mathrm{OH})_{2} \quad \text { (equation 2) }
$$

To synthesize hydroxyapatite (HAp), a phosphate precursor was needed, where in this study the precursor used was diammonium hydrogen phosphate $\left(\mathrm{NH}_{4}\right)_{2} \mathrm{HPO}_{4}$ with 1.67 mole ratio of $\mathrm{Ca} / \mathrm{P}$. Hydroxyapatite formation (HAp) can occurred at $\mathrm{pH} \mathrm{8-12} \mathrm{in} \mathrm{order} \mathrm{to}$ obtained high purity and stability (Tua et al., 2016). In this study set, the basic condition of pH 12 was controlled using $\mathrm{NaOH} 1 \mathrm{M}$. Samples was calcined at a temperature of 900 ${ }^{\circ} \mathrm{C}$ for 5 hours aimed to increasing the degree of crystallization (Haris et al., 2016), eliminate carbonate which can maximized the formation process of hydroxyapatite (HAp) (Ningsih et $a l ., 2014)$. Heating at $900{ }^{\circ} \mathrm{C}$ indicated that the samples used from the bones of the mackerel have a good thermal stability characterized by the formation of hydroxyapatite (HAp) (Royani et al., 2016). The reaction was in eq. 3.

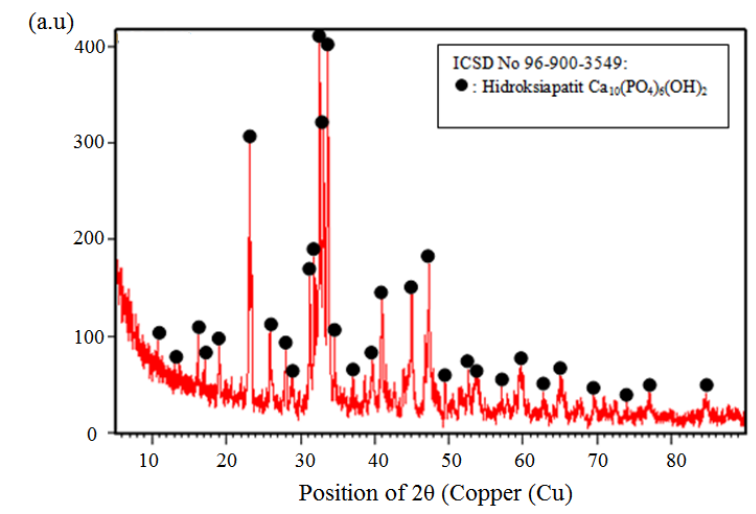

Figure 1. XRD analysis of hydroxyapatite

Fig. 1 shows the XRD pattern of hydroxyapatite compound of tenggiri bones. XRD analysis aims to determine the structure, orientation, and size of crystals (Munasir et al., 2012). XRD indicates the presence of hydroxyapatite (HAp) formed from calcium precursors derived from decomposition of mackerel bones and phosphate precursors derived from diammonium hydrogen phosphate. XRD X'PERT POWDER PW 30/40 analysis shows hydroxyapatite in accordance with ICSD standard 96-900-3549 which shows hydroxyapatite with chemical formula $\mathrm{Ca}_{10}\left(\mathrm{PO}_{4}\right)_{6}(\mathrm{OH})_{2}$ and crystal form in the form of hexagonal. Sharp peaks with high intensity can be seen at $2 \theta=32.58^{\circ}$ and other peaks with lower intensity at $21=33.71^{\circ} ; 33.14^{\circ}$; and $23.13^{\circ}$. In previous research, (Anggresani et al., 2018) shows hydroxyapatite with ICSD standard 01-074-9780 where the high intensity was located at $2 \theta=32.84^{\circ}$. Hydroxyapatite has many standards, this can be seen from some previous research on hydroxyapatite. However, a high intensity $2 \theta$ peak will be obtained at $32^{\circ}$.

$$
10 \mathrm{Ca}(\mathrm{OH})_{2}+6\left(\mathrm{NH}_{4}\right)_{2} \mathrm{HPO}_{4} \longrightarrow \mathrm{Ca}_{10}\left(\mathrm{PO}_{4}\right)_{6}(\mathrm{OH})_{2}+6 \mathrm{H}_{2} \mathrm{O}+12 \mathrm{NH}_{4} \mathrm{OH} \text { (equation 3) }
$$



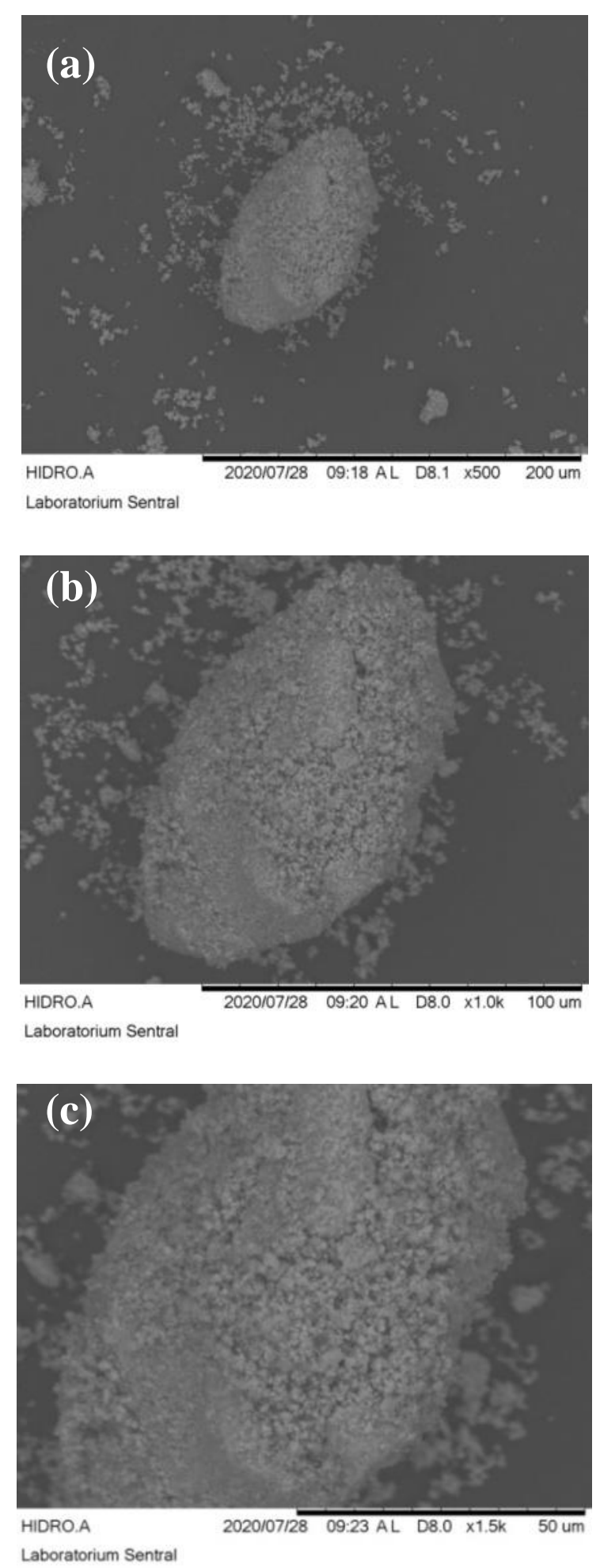

Figure 2. SEM images of obtained HAp with magnification (a) 500x ; (b) 1000x ; (c) 1500x

Fig. 2 shows the SEM image of hydroxyapatite compound of tenggiri fish bone with the magnification of 500,1000, and 1500 times which consisted of agglomerates. Based on (Hui et al., 2010) finding, the SEM images were the agglomerates with almost the same shapes. Previous investigation reported that the result of the surface morphology of hydroxyapatite in the form of agglomerates ( Ichsan \& Helwani, 2015).

\section{Toothpaste Evaluation}

In toothpaste making, hydroxyapatite was used as an abrasive materials. Formula 0 (F0) used $\mathrm{CaCO}_{3}$ abrasive materials for about $55 \%$, while F1, F2, and F3 used hydroxyapatite as an abrasive materials as much as $45 \%, 50 \%$, and $55 \%$, respectively. In the previous research, the addition of hydroxyapatite to toothpaste preparations was $15 \%$ (Sadiasa et al., 2013).

Organoleptic observations show all formulas smell of mint. (Afni \& Said, 2015) was investigated the smell of oleum menthol which can mask smell of other ingredients so that there were not difference in the aroma of hydroxyapatite toothpaste (HAp). The formula was white, because the ingredients used to formulate toothpaste were generally white. F2 was more solid than F1 and F3 was denser than $\mathrm{F} 1$ and F2, this was due to the concentration of hydroxyapatite powder (HAp) added more and more (Ningsih et al., 2015).

The results of the scatter power test of each formula (F0, F1, F2, and F3) of hydroxyapatite toothpaste (HAp) showed the ability to spread preparations getting more significant as the loading increased, F1 had a large dispersal power followed by F2, F0, and F3 respectively. (Andriana et al., 2011) studied the area of spread was directly proportional to the increase in loading addition, the greater the loading added the wider the scatter power generated. The viscosity of F0 and F3 was higher then followed by F2 then F1, respectively. Viscosity was inversely proportional to dispersability, the greater the viscosity, the smaller the scatter power (Numberi et al., 2020).

The stability test in 21 days showed F0 had discoloration and smell on the 14th day and the 21st day at each temperature. F1 experienced a change in the smell on the 14th day at $4{ }^{\circ} \mathrm{C}$ and $40^{\circ} \mathrm{C}$ and on the 21 st day at room temperature. The toothpaste formula $\mathrm{F} 0$, F1, F2, and F3 undergone homogeneity changes on the $21^{\text {st }}$ day at $40^{\circ} \mathrm{C}$. This can be caused by extreme storage temperatures causing unstable preparation. 
Table 3. Organoleptic test results and homogeneity of hydroxyapatic toothpaste (HAp)

\begin{tabular}{ccccc}
\hline \multirow{2}{*}{ Observations } & \multicolumn{4}{c}{ Formula } \\
\cline { 2 - 5 } & F0 & F1 & F2 & F3 \\
\hline Color & White & White & White & White \\
Shape & Semi solid & Semi solid & Semi solid & Semi solid \\
Odor & Mint & Mint & Mint & Mint \\
Homogenity & Homogeneous & Homogeneous & Homogeneous & Homogeneous \\
\hline
\end{tabular}

Description :

F0 : Toothpaste formulation without hydroxyapatite

F1 : Toothpaste formulation with $45 \%$ hydroxyapatite

F2 : Toothpaste formulation with $50 \%$ hydroxyapatite

F3 : Toothpaste formulation with $55 \%$ hydroxyapatite

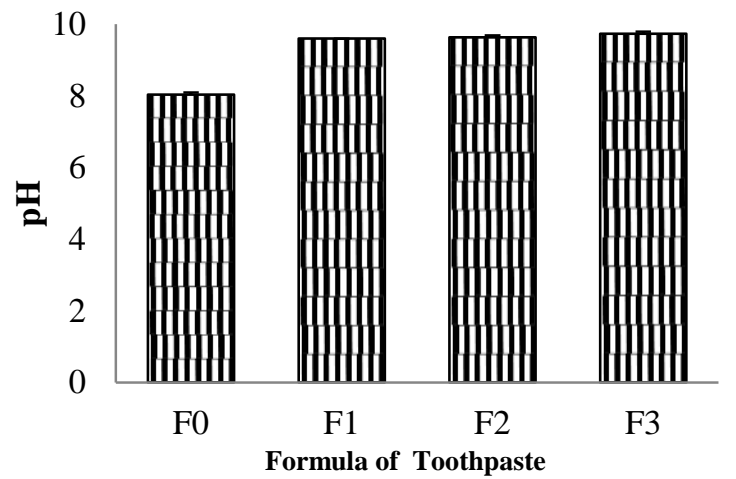

Figure 3. HAp toothpaste $\mathrm{pH}$ test result

Fig. 3 showed $\mathrm{pH}$ test results of each formula (F1,F2 and F3) of hydroxyapatite toothpaste (HAp) which have a range of 9.69.8. As for formula F0 has a range of $\mathrm{pH} 8-8.1$. This happened due to the ingredients used in the formulation were alkaline, such as hydroxyapatite (HAp), calcium carbonate, Na$\mathrm{CMC}$, and sodium lauryl sulfate, yet the preparation of hydroxyapatite toothpaste (HAp) is still within the permissible $\mathrm{pH}$ with the range of 4.5-10.5 (Mahdali et al., 2017). $\mathrm{pH}$ toothpaste that meets SNI (12-3524-1995) requirements is not expected to irritate the mucosa of the mouth.

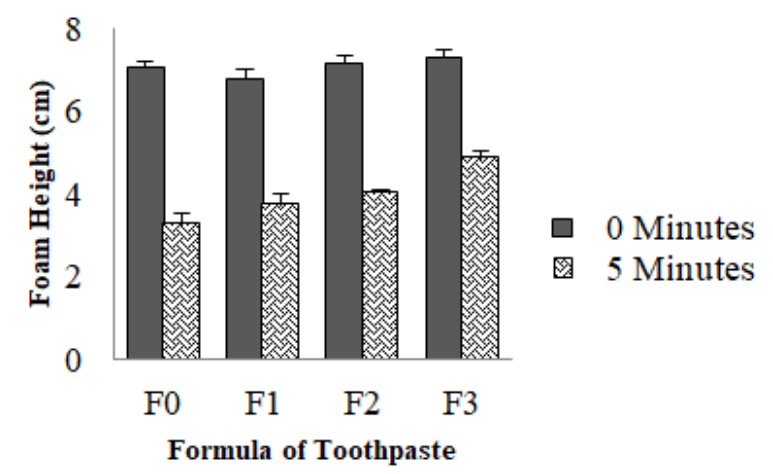

Figure 4. HAp toothpaste from height test results
The results of foam height testing showed the ability of a detergent to produce foam. There was no high foam requirement for a toothpaste product. It is attributed to the aesthetic value that consumers like (Daud et al., 2016). Based on high observations of foam in each formula (F0, F1, F2 and F3), they have almost the same height of foam. This was due to the sodium lauryl sulfate detergent agent being added in the same percentage. SLS was an anionic surfactant with characteristics as a good foam shaper and has high cleaning power (Syurgana et al., 2017).

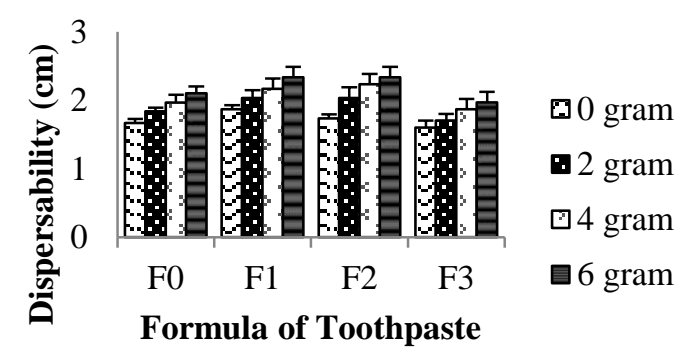

Figure 5. HAp toothpaste spread test result

After stored each formula (F1, F2 and F3) for 21 days, the preparation undergoes a change in $\mathrm{pH}$ in each temperature on a weekly date in the range of 9.1-9.7, while F0 in the range of 7.4-8. Changes in $\mathrm{pH}$ values in each formula are caused by environmental factors such as extreme temperature, humidity and storage containers (Afni \& Said, 2015). It is suspected that there was a reaction between hydroxyapatite (HAp) and sodium that triggered the formation of alkaline, but the preparation of hydroxyapatite toothpaste (HAp) was still within the permissible $\mathrm{pH}$ 
requirement range of 4.5-10.5 (Badan Standar Nasional (SNI), 1995).

The height of each formula of hydroxyapatite toothpaste (HAp) (F1, F2 and F3) after 21 days of storage experienced no significant difference, but F0 had a lower foam height on the 7 th to 21 st day of each storage temperature. However, hydroxyapatite toothpaste (HAp) preparations still qualified for foam ability that lasts after 5 minutes which is $60 \%-70 \%$ (Benediktus, 2017).

The increase in the number of hydroxyapatite (HAp) increases the diffusion power of the preparations in each formula. This happened because the more hydroxyapatite (HAp) that was added, the more dense the preparation (Ningsih et al., 2015). Based on the results of spread tests showed that hydroxyapatite toothpaste (HAp) stored at $4{ }^{\circ} \mathrm{C}$ had a greater spread than stored at room temperature. It was because storage at $4{ }^{\circ} \mathrm{C}$ had higher humidity and low viscosity than storage at room temperature. Storage at 40 ${ }^{\circ} \mathrm{C}$ had a higher temperature than storage at room temperature thus reducing the amount of water found in toothpaste that can affected viscosity (Lupita \& Kadiwijati, 2019). This happened because of the storage temperature and is thought to occurred because the storage container is made of glass so that at $4{ }^{\circ} \mathrm{C}$ it can absorb water and at $40{ }^{\circ} \mathrm{C}$ it can reduce water. Hydroxyapatite toothpaste preparations (HAp) should be stored at room temperature.

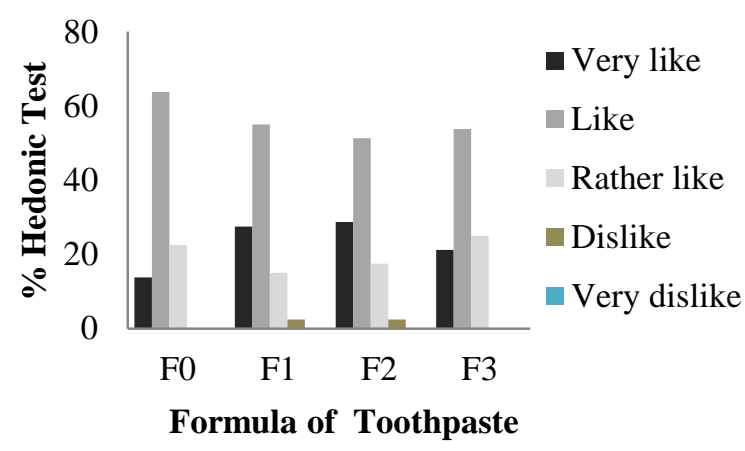

Figure 6. HAp Toothpaste Hedonic Test

Hedonic test of each hydroxyapatite toothpaste (HAp) preparation against 20 volunteers on average liked each formula of toothpaste both in terms of color, aroma, taste and texture, but there were 2 volunteers who did not like the texture of toothpaste from F1 and F2. Hedonic test observations can be concluded that the most preferred percentage of color, aroma, taste and texture is formula F1.

\section{CONCLUSIONS}

Hydroxyapatite which was synthesized from tenggiri fish bones can be formulated into toothpaste and the best formula was F1 with a concentration of 50\% Hydroxyapatite (HAp).

\section{ACKNOWLEDGEMENTS}

The author's gratitude to the DIKTI who funded this research through the SIMBELMAWA (PKM) program in the 2019/2020 funding period.

\section{REFERENCES}

Jadge DR, Patil SV, Purohit RN. 2008. Formulation of toothpaste from various forms and extracts of tender twigs of neem. Journal of Pharmacy Research. 1(2): 148-152.

Afni N, Said N. 2015. Uji aktivitas antibakteri pasta gigi ekstrak biji pinang (Areca catechu L .) terhadap Streptococcus mutans dan Staphylococcus aureus. Journal of Pharmacy. 1(March): 48-58.

Ahmad I. 2017. Pemanfaatan limbah cangkang kerang darah (Anadara granosa) sebagai bahan abrasif dalam pasta gigi. Jurnal Galung Tropika. 6(1): 49-59. https://doi.org/10.31850/JGT.V6I1.210

Ali A, Milala MA, Gulani IA. 2015. Antimicrobial effects of crude bromelain extracted from pineapple fruit (Ananas comosus Linn.). Advances in Biochemistry 2015. 3(1): 1-4. https://doi.org/10.11648/j.ab.20150301.11

Andriana IKA, Murrukmihardi M, Ekowati D. 2011. Pengaruh konsentrasi tragakan terhadap mutu fisik sediaan pasta gigi ekstrak etanolik daun mahkota dewa (phaleria papuana Warb var. Wichnannii) sebagai antibakteri Streptococcus mutans. Jurnal Farmasi Indonesia. 8(1): 66-76.

Anggresani L. 2016. Dip-costing senyawa kalsium fosfat dari batu kapur bukit tui dengan variasi rasio mol $\mathrm{Ca} / \mathrm{P}$ melalui metode solgel. Sainstek: Jurnal Sains Dan Teknologi. 7(1): 33. https://doi.org/10.31958/js.v7i1.123

Anggresani L, Perawati S, Rahayu IJ. 2018. Limbah tulang ikan tenggiri (Scomberomorus guttatus) sebagai sumber kalsium pada 
pembuatan hidroksiapatit. Jurnal Katalisator. 3(2): 153-161.

Azis Y, Jamarun N, Zultiniar AS, Nur H. 2015. Synthesis of hydroxyapatite by hydrothermal method from cockle shell (Anadara granosa). Journal of Chemical and Pharmaceutical Research. 7(5): 798-804.

Badan Standar Nasional (SNI), Pub. L. No. 123524-1995 (1995).

Benediktus. 2017. Mutu fisik sediaan shampo cair ekstrak mengkoang (Nothopanax scutellarium Merr). Akademi Farmasi Putra Indonesia Malang. 1-10.

Budiatin AS, Khotib J, Hasmono D. 2016. Injektabel komposit hydroksiapatit-gelatin sebagai sistem penghantaran alendronat. Jurnal Farmasi Dan Ilmu Kefarmasian Indonesia. 3(1): 1-5.

Daud NS, Desi SA, Ifaya M. 2016. Formulasi pasta gigi infusa daun jambu biji (Psidium Guajavalinn) dengan variasi konsentrasi Na. Cmc Sebagai Bahan Pengikat. Jurnal Ilmiah Ibnu Sina. 1(1): 42-49.

Siregar YDI, Utami P. 2014. Pemanfaatan ekstrak kulit melinjo merah ( Gnetum Gnemon ) sebagai Pewarna Alami pada Pembuatan Lipstik. Jurnal Kimia Valensi, 4(2), 98-108.

Hanura AB, Trilaksani W, Suptijah P. 2017. Karakterisasi nanohidroksiapatit tulang tuna Thunnus sp sebagai sediaan biomaterial. Jurnal Ilmu Dan Teknologi Kelautan Tropis. 53(9): 619-629. https://doi.org/10.1017/CBO9781107415324 .004

Haris A, Fadli A, Yenti SR. 2016. Sintesis hidroksiapatit dari limbah tulang sapi menggunakan metode presipitasi dengan variasi rasio $\mathrm{Ca} / \mathrm{P}$ dan konsentrasi $\mathrm{H}_{3} \mathrm{PO}_{4}$. JOM FTEKNIK. 3(2): 1-10.

Hui P, Meena SL, Singh G, Agarawal RD, Prakash S. 2010. Synthesis of hydroxyapatite bioceramic powder by hydrothermal method. Journal of Minerals and Materials Characterization and Engineering. 09(08): 683-692.

https://doi.org/10.4236/jmmce.2010.98049

Ismail I, Ningsi S, Tahar N. 2014. Pengaruh jenis pengikat terhadap sifat fisika sediaan serbuk masker wajah kulit buah semangka (Citrullus vulgaris Schrad). Jurusan

\section{Farmasi Fakultas Ilmu Kesehatan Universitas Islam Negeri Alauddin Makassar. 2(2): 80-86.}

Lupita, Kadiwijati LR. 2019. Pengaruh perbedaan konsentrasi ekstrak etanol $70 \%$ daun landep (Barleria prionitis L.) dalam formulasi sediaan pasta gigi terhadap sifat fisik, stabilitas fisik dan aktivitas antibakteri pada bakteri Streptococcus mutans. Jurnal Sains Dan Teknologi. 15(7): 1-16.

Mahdali A, Widarsih E, Harismah K. 2017. Pengujian sifat fisika dan sifat kimia formulasi pasta gigi gambir dengan pemanis alami daun stevia. The 6th University Research Colloquium 2017. 135-138.

Manggara AB. 2018. Analisis kandungan mineral daun kelor (Moringa oleifera Lamk.) menggunakan spektrometer XRF. Akta Kimia Indonesia. 3(1): 104-111.

Munasir, Triwikantoro, Zainuri, Darminto. 2012. Uji XRD dan XRF pada bahan meneral (batuan dan pasir) sebagai sumber material cerdas $\left(\mathrm{CaCO}_{3}\right.$ dan $\left.\mathrm{SiO}_{2}\right)$. Jurnal Penelitian Fisika Dan Aplikasinya (JPFA). June. https://doi.org/10.26740/jpfa.v2n1.p20-29

Mustaqim A. 2017. Analisa kuat tekan dan kekerasan material biokomposit hidroksiapatit tulang sapi/ shellac /tapioka. Solo (ID): Universitas Sebelas Maret.

Mutmainnah M, Chadijah S, Rustiah WO. 2017. Hidroksiapatit dari tulang ikan tuna sirip kuning (Tunnus albacores) dengan metode presipitasi. Al-Kimia. 5(2): 119-126. https://doi.org/10.24252/al-kimia.v5i2.3422

Nagajyothi A, Gorantla N, Pavan R, Sreedhar AA. 2014. Formulation and evaluation of herbal ointments containing aqueous extract of AcalyphaIndica using different types of ointment bases. International Journal of Chemistry and Pharmaceutical Sciences. 2(11): 1276-1280.

Ningsih RP, Wahyuni N, Destiarti L. 2014. Sintesis hidroksiapatit dari cangkang kerang kepah (Polymesoda erosa) dengan variasi waktu pengadukan. Jurnal Kimia Khatulistiwa. 3(1): 22-26.

Ningsih S, Hidayati L, Akbar R. 2015. Pasta zinc oxide sebagai mild astrigent menggunakan basis amilum singkong (Manihot utilisima pohl). Jurnal Farmasi Dan Ilmu Kefarmasian Indonesia. 7(2): 95-103. 
Numberi AM, Dewipratiwi R, Gunawan E. 2020.

Uji stabilitas fisik sediaan masker gel dari ekstrak alga merah (Poryphyra sp). Majalah Farmasetika. 5(1) 1-17. https://doi.org/10.24198/mfarmasetika.v5i1. 24066

Ichsan RHNA, Helwani Z. 2015. Sintesis hidroksiapatit melalui precipitated calcium carbonate (pcc) dari cangkang kerang darah dengan metode hidrotermal pada variasi waktu reaksi dan rasio $\mathrm{Ca} / \mathrm{P}$. JOM FTEKNIK. 2(2): 1-9. https://doi.org/10.20555/kokugoka.71.0_80

Rajesh R, Ayyamperumal H, Natarajan S, Ravichandran D. 2012. Chitosan and natural hydroxyapatite derived from the chicken bones wasted. International Journal of Pharmacy and Pharmaceutical Sciences. 4(August): 716-720.

Riyanto B, Maddu A. 2014. Material biokeramik berbasis hidroksiapatit tulang ikan tuna. Jurnal Pengolahan Hasil Perikanan Indonesia. 16(2): https://doi.org/10.17844/jphpi.v16i2.8046

Royani A, Sulistiyono E, Sufiandi D. 2016. Pengaruh suhu kalsinasi terhadap dekomposisi dolomit. Jurnal Sains Materi Indonesia. 18(1): 41-46.

Sadiasa A, Dong-Woo J, Deb Nath S, Seo HS, Yang HM, Lee BT. 2013. Addition of hydroxyapatite to toothpaste and its effect to dentin remineralization. Korean Journal of Materials Research. 23(3): 168-176. https://doi.org/10.3740/MRSK.2013.23.3.16 8

Sidiqa A, Djustiana N, Sunendar B, Febrida R. 2012. Surface modification of multilayer coatings Ti-Al-Cr and hydroxyapatite on calcium phosphate cement with sol-gel method. Journal of Dentistry Indonesia. 19(2): 43-46.

Stanek M, Peter E, Janicki B. 2013. Content of the calcium and phosphorus in the meat of Prussian carp (Carassius auratus gibelio BLOCH, 1783) from the Lake Gopło (Poland). Journal of Central European Agriculture. $14(1)$ : 1-10. https://doi.org/10.5513/JCEA01/14.1.1145

Susanti L, Zuki M, Syaputra F. 2011. Pembuatan mie basah berkalsium dengan penambahan tulang ikan tenggiri (Somberomorus lineolatus). Jurnal Agroindustri. 1(1): 3544.

https://doi.org/10.31186/j.agroind.1.1.35-44

Syurgana MU, Febrina L, Ramadhan AM. 2017. Formulasi pasta gigi dari limbah cangkang telur bebek. Proceeding of the 6th Mulawarman Pharmaceuticals Conferences, November: 7-8.

Tua B, Amri A, Zultiniar. 2016. Sintesis dan karakterisasi hidroksiapatit dari cangkang kerang darah dengan proses hidrotermal variasi suhu dan pH. Jom FTEKNIK. 3(2): 15.

Wadu I, Rohaini IK, Gintu AR, Hartini S. 2015. Pasta gigi pencegah gigi berlubang berbahan aktif mikro hidroksiapatit (Hap) dari limbah kerabang telur pasar raya kota Salatiga. Program SIMLITABLAS (PKM). 116-124.

Wattanutchariya W, Changkowchai W. 2014. Characterization of porous scaffold from chitosan-gelatin/hydroxyapatite for bone grafting. Lecture Notes in Engineering and Computer Science, 2210(January). 